\title{
RANCANG BANGUN DAN UJI COBA TUNGKU KRUSIBEL DARI TABUNG GAS BEKAS DENGAN MENGGUNAKAN SUMBER PANAS GAS LPG
}

\author{
Aminur ${ }^{1}$, Kadir $^{2}$, Muhammad Hasbi ${ }^{3}$, Sudarsono ${ }^{4}$, Yuspian Gunawan ${ }^{5}$, La Hasanudin ${ }^{6}$, Raden \\ Rinova Sisworo ${ }^{7}$, Al Ichlas Imran ${ }^{8}$
}

Jurusan Teknik Mesin Fakultas Teknik Universitas Halu Oleo, Kendari

Email: ${ }^{1}$ aminur@uho.ac.id, ${ }^{2}$ irkadir69@gmail.com, ${ }^{3}$ muh.hasbi74@gmail.com, ${ }^{4}$ chono_mesin@yahoo.com, ${ }^{5}$ yuspian.gunawan@yahoo.com, ${ }^{6}$ hasanudin.acang@yahoo.co.id, 7rinova.indonesia@gmail.com, ${ }^{8}$ aichlas@gmail.com

\begin{abstract}
Abstrak
Ketersediaan tungku krusibel saat ini masih terbatas sehingga harganya dipasaran relatif mahal padahal alat ini sangat penting peranannya khusunya pada institusi pendidikan sebagai media praktek pengecoran logam. Tujuan penelitian ini adalah merancang, membuat, menguji coba kerja tungku krusibel yang memanfaatkan tabung bekas dengan menggunakan sumber panas gas LPG dengan parameter uji berat aluminium terhadap waktu peleburan. Perancangan tungku menggunakan aplikasi autodesk inventor sedangkan pembuatannya menggunakan perkakas mesin. Data tehnis dari tungku krusibel ini adalah bodi dibuat dari tabung gas bekas dengan tebal plat $2,9 \mathrm{~mm}$, diameter luar $280 \mathrm{~mm}$, diameter dalam $140 \mathrm{~mm}$, dan tinggi tinggi $490 \mathrm{~mm}$. Pada ruang bakar dipasang pipa saluran gas diameter $25,4 \mathrm{~mm}$ dengan panjang $370,5 \mathrm{~mm}$ dan saluran udara diameter $50,8 \mathrm{~mm}$ dengan panjang $367 \mathrm{~mm}$. Kowi dibuat dari bahan baja dengan dimeter $110 \mathrm{~mm}$ dan tinggi $280 \mathrm{~mm}$. Hasil uji coba dengan peleburan aluminium menunjukkan bahwa tungku krusibel mampu meleburkan aluminium $5 \mathrm{~kg}$ selama 60 menit dengan komsumsi bahan bakar 3 gas kg. Suhu maksimum yang dapat dicapai $1367{ }^{\circ} \mathrm{C}$ selama 15 menit oleh tungku krusibel.
\end{abstract}

Kata kunci: Kata kunci: perancangan, pembuatan, uji coba tungku

\begin{abstract}
The availability of crucible furnaces is still limited, so the price in the market is relatively expensive, even though this tool is very important, especially in educational institutions as media for the practice of metal casting. The purpose of this study is to design, manufacture, and test the work of a crucible furnace that utilizes used cylinders by using a heat source of LPG gas with a parameter of weight testing of aluminum against melting time. The design of the furnace uses the autodesk inventor application while the manufacture uses machine tools. Technical data from this crucible furnace is that the body is made from used gas cylinders with an outer diameter of $280 \mathrm{~mm}$, an inner diameter of $140 \mathrm{~mm}$ and a height of $490 \mathrm{~mm}$. In the combustion chamber installed a $25.4 \mathrm{~mm}$ diameter gas pipeline with a length of $370.5 \mathrm{~mm}$ and an air channel diameter of $50.8 \mathrm{~mm}$ with a length of $367 \mathrm{~mm}$. Kowi is made of steel with a $110 \mathrm{~mm}$ dimension and a height of $280 \mathrm{~mm}$. The results of trials with aluminum smelting show that the crucible furnace is capable of melting $5 \mathrm{~kg}$ aluminum for 60 minutes with fuel consumption of $3 \mathrm{~kg}$ gas. The maximum temperature that can be reached 1367 oC for 15 minutes by a crucible furnace.
\end{abstract}

Keywords: design, manufacture, furnace trials 


\section{PENDAHULUAN}

Industri pengecoran logam khususnya aluminium berkembang dengan pesat hal ini sebabkan karena penggunaannya yang cukup luas dalam berbagai aspek diantaranya komponen otomotif, pesawat terbang bahkan sebagai perabot rumah tangga. Untuk meleburkan logam khususnya aluminium dibutuhkan alat berupa tungku dan yang paling sering digunakan adalah tungku krusibel. Sampai saat ini, kebanyakan tungku krusibel yang digunakan oleh home industri dan lembaga pendidikan merupakan bahan impor dan harganya relatif mahal sehingga hal ini berdampak pada besarnya investasi yang dibutuhkan bagi pelaku usaha dan bagi institusi pendidikan keberadaannya masih terbatas. Dalam perancangan tungku krusibel pada penelitian didasarkan oleh beberapa pertimbangan diantaranya mudah pindahkan, biaya perawatannya rendah, mudah dalam fabrikasi, sistem operasi yang sederhana, biaya pembuatan rendah dan biaya operasional yang terjangkau.

Tungku krusibel merupakan jenis tungku peleburan skala kecil, sederhana, dan paling tuadilengkapi wadah yang disebut kowi sebagai tempat untuk meleburkan logam (Arifin, 1976). Kowi berbentuk krus yang dapat direncanakan secara tetap, tidak tetap atau juga dapat ditungkik. Tungku krusibel menggunakan sumber panas yang dipeoleh dari pembakaran kokas/arang, minyak dan gas (Arianto, Tiwan, \& Mujiyono, 2017).

Perubahan fase padat ke fase cair dapat dilakukan melalui proses peleburan dan pengecoran dengan menggunakan tungku yang disesuaikan dengan jenis dan jumlah bahan yang dilebur (Ana, Wanga, Lia, \& Liub, 2012). Peleburan logam paduan ringan dapat diproses dengan menggunakan tungku krusibel, sedangkan untuk meleburkan logam besi cor digunakan tungku induksi frekuensi rendah atau kupola. Selain itu, peleburan baja digunakan tungku induksi frekuensi tinggi. Dalam desain tungku ada beberapa pertimbangan, yaitu jenis logam yang akan dicor, temperatur lebur dan penuangan, kapasitas tungku yang mampu dilebur, kemudahan mengeporasikan, perawatan, dan ramah lingkungan (Hill, 1979).

Beberapa tungku pengecoran logam yang telah rencanakan, dibuat dan dikembangkan oleh beberapa peneliti diantaranya: Desain tungku elektrik (elektric furnace) untuk memproses dekomposisi thermal senyawa thorium oxalate hexahydrate. Pada penelitian ini dimensi ruang tungku adalah $0,9 \times 0,6 \times 0,6 \mathrm{~m}$ yang berbentuk rectangular dengan volume ruang $0,3 \mathrm{~m}$. Konstruksi tungku terbuat dari bahan SS-31L, batu tahan api dengan tebal 3 inci sebagai isolator, daya listrik untuk pembangkitan panas $20 \mathrm{~kW}$ (Jami \& Prayitno, 2015). Kelemahan tungku elektrik adalah biaya operasional yang tinggi dan ketergantungan pada sumber energi listrik.

Pemanfaatan oli bekas sebagai bahan bakar dalam perancangan dan pembuatan tungku peleburan logam dalam rangkah menumbuhkan industri lokal berbasis home industry dalam mendaur ulang logam bekas dengan titik lebur rendah melalui teknologi peleburan dan pengecoran logam. Metode yang digunakan adalah perlakuan atomizing pada oli bekas sehingga mudah terbakar. Hasil yang dicapai bahwa peleburan logam alumunium $1 \mathrm{~kg}$ alumunium mampu dilakukan peleburan selama 50 menit 32 detik dengan jumlah Oli bekas sebanyak 1/2 liter (Akhyar, 2014). Kelemahan jenis tungku ini adalah saluran oli harus sering dikotrol untuk mencegah menyumbatan dan adanya asap hasil pembakaran.

Perancangan tungku model silinder dengan bahan isolator refactory semen tahan api dan glass wool, sebagai sumber panas digunakan oli bekas. Dimensi tungku adalah diameter $48 \mathrm{~cm}$, tinggi $43 \mathrm{~cm}$ dan diameter krusibel $26 \mathrm{~cm}$ dan tinggi $39 \mathrm{~cm}$. Dari percobaan untuk mencapai temperatur $660{ }^{\circ} \mathrm{C}$ dibutuhkan \pm 24 menit dan temperatur yang dapat dicapai 887 oC. Sedangkan pada peleburan logam aluminium padat $0,5,1$, dan, $1,5 \mathrm{~kg}$ dibutuhkan waktu \pm 29 -34 untuk mencairkan (Stana, Ridwan, \& Rilnanda, 2017). Kelemahan membutuhkan bahan tambah minyak tanah, oli harus disaring terlebih dahulu sebelum digunakan dan menghasilkan asap hitam pada proses pembakaran.

Prototipe tungku krusibel kompak mini dikembangkan dengan metode reserach and development. Prototipe tungku krusibel kompak mini yang dibuat berdimensi diameter luar $330 \mathrm{~mm}$, diameter dalam 150 dan tinggi $750 \mathrm{~mm}$ dengan bobot tungku $46 \mathrm{~kg}$. Tungku dibuat dari drum bekas dengan isolator panas kombinasi dari selimut keramik D.96 dan castable TNC 17. Tungku ini dapat meleburkan $3 \mathrm{~kg}$ aluminium dalam waktu 50 menit dengan komsumsi gas LPG 1,76 kg (Leman, Amri, P, Y, \& S, 2019). Kelemahan adanya api balik yang keluar disaluran pembuangan dan kehilangan panas cukup besar pada dinding tungku.

Penelitian perancangan, pembuatan dan pengujian tungku dengan parameter waktu peleburan dan konsumsi bahan bakar. Jenis dapur peleburan adalah jenis krusibel pembakaran langsung dengan sumber panas gas elpiji. Metode penelitiannya adalah perancangan dan pembuatan serta pengujian tungku krusibel. Dimensi dapur peleburan adalah diameter $0,298 \mathrm{~m}$ dan tinggi 0,373 
m serta kapasitas kowi 11,6 kg. Waktu peleburan logam 0,82 jam dengan komsumsi bahan bakar 2,5 liter (Irvan \& Suryadi, 2017). Kelemahan alat ini adalah komsumsi bahan bakar yang kurang efisien untuk mencairkan aluminium.

Sumber energi untuk penggunaan bahan bakar tungku banyak ragamnya sehingga penggunaannya pun juga tergantung dari desain tungku yang direncanakan (Adi, Raharjo, \& Surojo, 2014). Diantara tiga jenis bahan bakar ini arang kayu, batu bara dan gas elpiji yang tinggi nilai kalor bakarnya adalah gas elpiji (Irvan \& Suryadi, 2017), selain dengan adanya regulasi pemerintah saat ini yang menarik subsidi minyak tanah dan mengalihkan ke gas elpiji menjadikan bahan bakar ini tersedia cukup banyak di agen bahkan sampai ke kios kecil. Perancangan tungku krusibel berbahan bakar gas dengan memanfaatkan tabung bekas didasarkan dengan beberapa pertimbangan diantaranya bahan mudah didapatkan karena bahannya dari tabung bekas, biaya pembuatan lebih rendah karena tidak membutuhkan pengerjaan pengerolan plat, ramah lingkungan dan operasinya mudah karena bahan bakarnya dari gas dan mudah terbakar serta nilai kalornya tinggi. Target akhir yang ingin dicapai adalah dihasilkan tungku krusibel low cost namun mampu meleburkan aluminium dengan waktu yang cepat dan komsumsi bahan bakar yang rendah.

\section{METODE}

Penelitian ini terlebih dahulu dilakukan telaah jurnal dan observasi di laboratorium manufaktur. Dari informasi yang didapatkan dibuatlah konsep dengan melibatkan beberapa aspek rancangan tungku krusibel seperti ketersediaan bahan, kemampuan manufaktur alat, kemudahan pengoperasian dan nilai keekonomisan dari biaya operasional.

Alat yang digunakan untuk melaksanakan penelitian ini terdiri dari perkakas mesin dan alat bantu lainnya diantaranya mesin las, gerinda potong, mesin bor, sedok semen dan digital thermometer thermocouple. Bahan yang digunakan untuk membuat tungku terdiri dari tabung bekas LPG dengan ketebalan plat 2,9 mm, diameter luar $280 \mathrm{~mm}$, diameter dalam $140 \mathrm{~mm}$, dan tinggi tinggi $490 \mathrm{~mm}$. Tabung LPG merupakan konstruksi utama yang menopang bahan isolator, pipa, tutup dan kowi. Pipa terdiri dari dua ukuran yaitu 2 inch $(50,8$ $\mathrm{mm}$ ) untuk saluran udara masuk dari blower dan 1/2 inch $(25,4 \mathrm{~mm})$ sebagai saluran masuk gas yang ditempatkan di dalam saluran udara. Isolator keramik terdiri dari campuran semen tahan api dan pasir tanah liat, abu terbangdan air. Cawan sebagai wadah untuk meleburkan aluminium pada proses pengecoran.

Perancangan tungku krusibel melalui tahapan:

1. Perancangantungku krusibel

Desain tungku krusibel diawali dengan membuat sketsa dan menerapkan konsep desain pada aplikasi Autodesk Inventor. Dari konsep dikembangkan menjadi sebuah tungku krusibel dengan memproyeksikan kedalam beberapa tampak. Tungku krusibel terdiri dari beberapa bagian utama yaitu badan berbentuk silider, isolator keramik, mekanisme tutup dan cawan.

2. Pembuatan tungku krusibel

Berdasarkan rancangan maka dibuatlah tungku krusibel dimana tahapan yang dilakukan adalah: Pertama tabung gas bekas LPG diberi tanda pada bagian yang akan diukur setelah itu dilakukan pengukuran sesuai dengan ukuran yang ada pada gambar kerja. Pada pembuatan bodi, ada dua pekerjaan yang akan dilakukan yaitu pemotongan pada tutup tabung dan pembuatan lubang saluran udara dan gas pada bagian alas tabung. Kedua pipa saluran masuk gas dan udara blower diukur sesuai ukuran yang dibutuhkan dan dipotong dengan mesin gerinda. Pada lubang yang ada pada tabung gas dimasukkan pipa saluran udara masuk dan gas kemudia las disekeliling bagian tepinya agar tidak terjadi kebocoran udara dan gas. Ketiga sisa potongan pada bagian atas dibuat tutup tungku dimana pada bagian ini dipasang mekanisme handel buka tutup dan pada bagian lainnya dipasang mekanisme engsel agar dapat berputar berlawanan arah jarum jam dan juga tutup dapat dilepas-lepas. Keempat pemasangan bahan isolator keramik dengan cara membuat adonan dari campuran semen tahan api, tanah liat dan abu terbang serta air secukupnya yang dicetak di dalam rangka tabung. Adonan campuran diisi secara merata keseluruh bagian tungku dan dibiarkan sampai kering sempurna. Kelima pemasangan dudukan cawan pada dinding isolator keramik.

3. Perakitan komponen pendukung

Pemasangan komponen-komponen pendukung seperti burner, selang gas, regulator, gas LPG, blower dipasang secara utuh pada tungku krusibel.

4. Uji coba alat

Uji coba kerja tungku krusibel dengan parameter yaitu pengukuran suhu maksimum yang dapat dicapai oleh tungku selama beberapa menit dengan menggunakan alat ukur digital digital thermocouple yang terpasang pada dinding 
bagian ruang bakar dan bagian luar. Melaksanakan peleburan aluminium dengan berat yang berbeda dan mencatat waktu disetiap proses peleburan. Melakukan peleburan aluminium dengan jumlah $5 \mathrm{~kg}$ menghitung komsumsi bahan bakar yang dihabiskan.

\section{HASIL DAN PEMBAHASAN}

Rancangan tungku krusibel terdiri dari lima bagian rancangan masing-masing diproyeksikan kedalam beberapa tampak.

\section{Rancangan Tungku Krusibel}

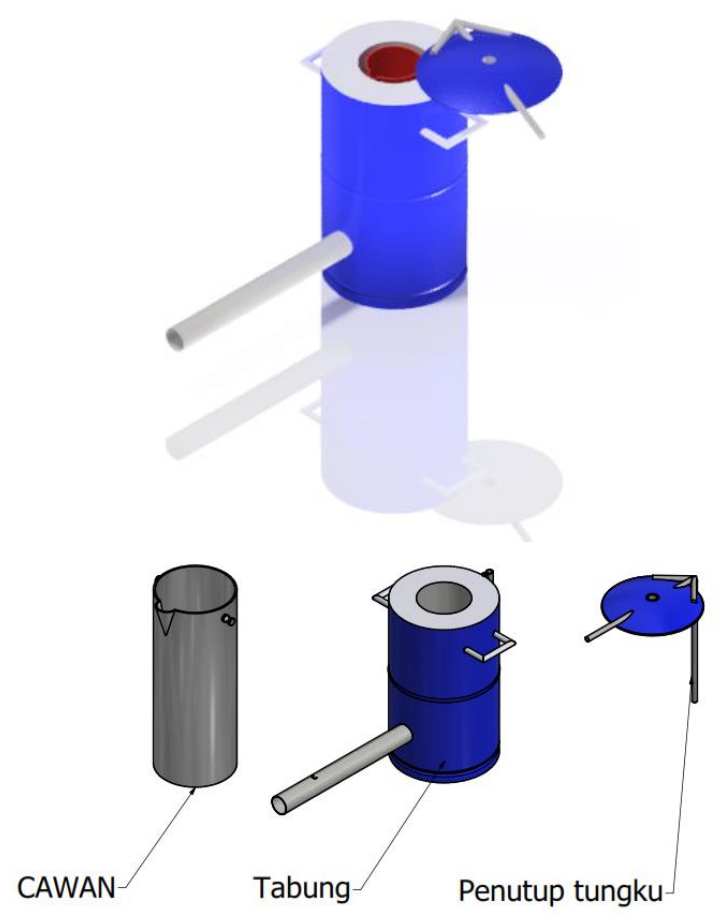

Gambar 1. Desain tungku krusibel dan bagianbagiannya
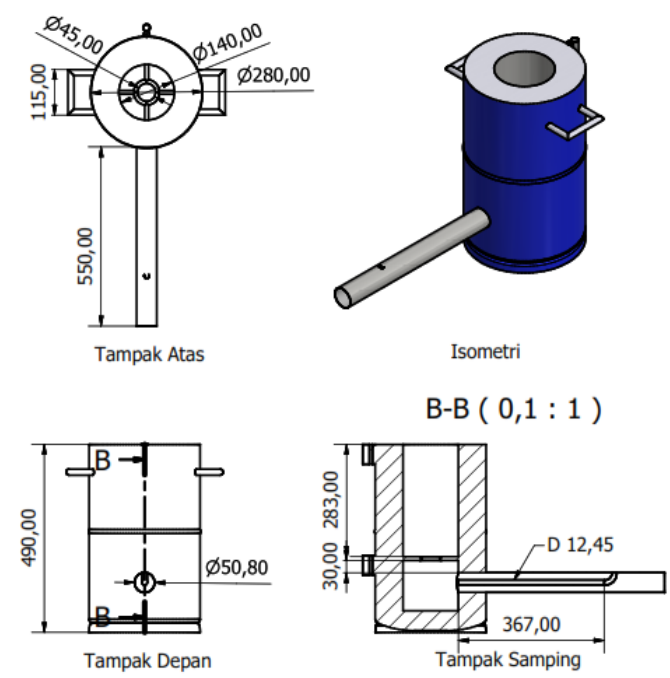

Gambar 2. Gambar potongan B-B tungku krusibel
Dari konsep tungku krusibel yang telah dibuat selanjutnya diproyeksikan menjadi beberapa bagian komponen dalam berbagai tampak.

Beberapa bagian utama tungku krusibel terdiri dari yaitu badan berbentuk silider, isolator keramik, mekanisme tutup dan kowi.

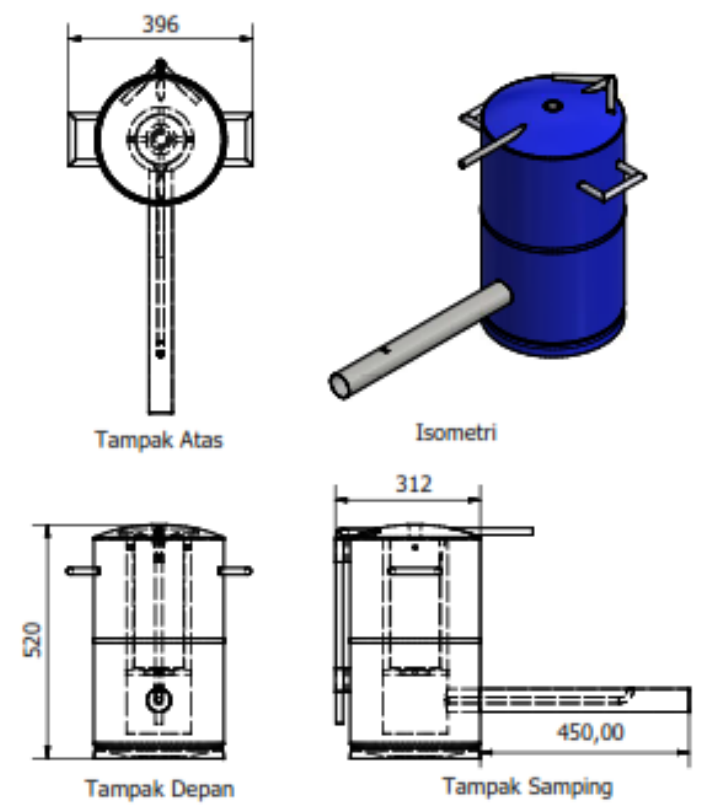

Gambar 3. Desain proyeksi tampak tungku krusibel
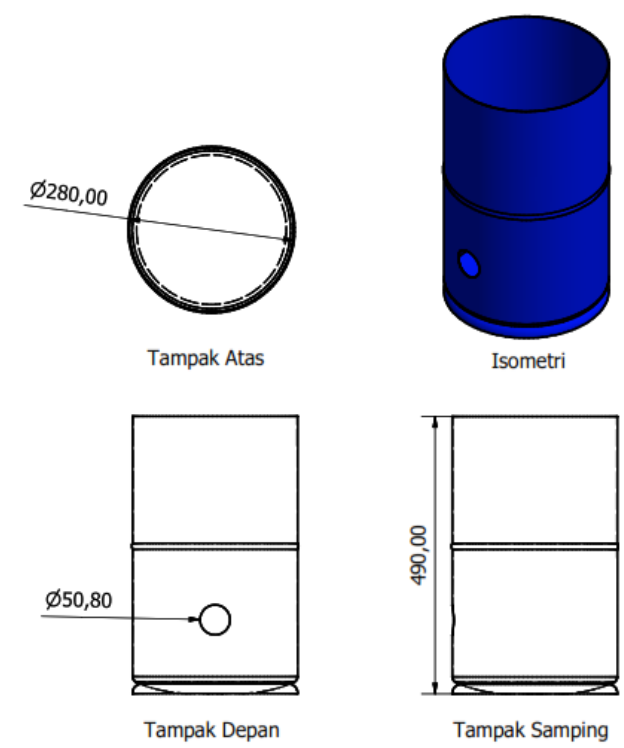

Gambar 3. Desain bodi tungku krusibel 

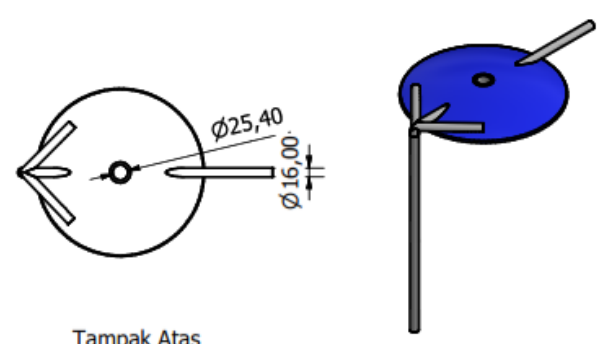

Tampak Atas

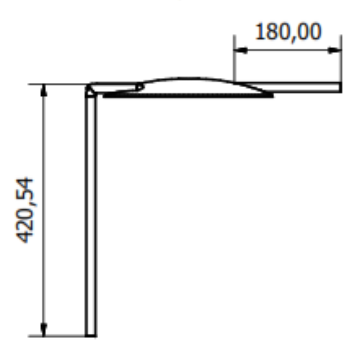

Tampak Depan

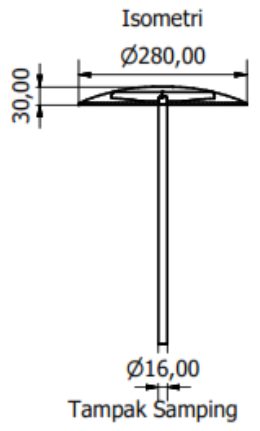

Gambar 4. Desain tutup tungku krusibel

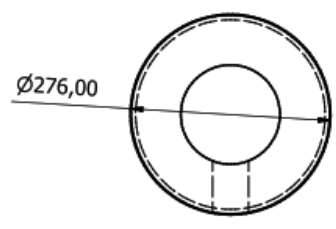

Tampak Atas

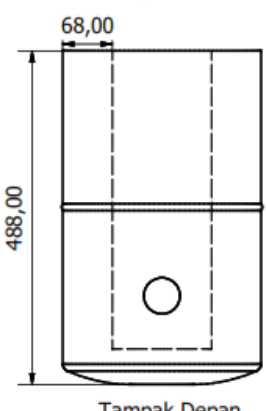

Tampak Depan

Gambar 4. Desain isolator keramik

\section{Prosedur Pembuatan Tungku Krusibel}

a. Pembuatan bodi tungku dan pemasangan pipa saluran

Pertama-tama, tabung gas LPG bekas dipotong dengan panjang $490 \mathrm{~mm}$ dan dibuat lubang diameter 50,8 mm dari jarak alas 126,2 mm. Kedua, pipa saluran udara masuk diameter 50,8 $\mathrm{mm}$ dipotong dengan panjang $500 \mathrm{~mm}$ dan pada jarak 370,5 mm dibuat lubang diameter 25,4 mm. Ketiga, pada pipa saluran udara masuk dipasang pipa saluran gas masuk diameter 25,4 $\mathrm{mm}$ dengan panjang $367 \mathrm{~mm}$ dan pada bagian ujung dipasang bengkokan yang dilas dengan pipa. Kedua pipa saluran masuk dipasang pada lubang yang ada pada tabung untuk dilas. Volume ruang bakar yang direncakan adalah sebesar $1424,78 \mathrm{~mm}^{3}$ dan volume ruang cawan $2659,58 \mathrm{~mm}^{3}$ sehingga total keseluruhan volume ruang bakar dan cawan adalah 4084,36 $\mathrm{mm}^{3}$.

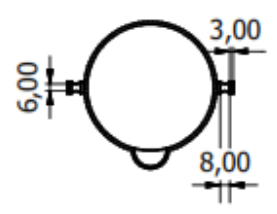

Tampak Atas

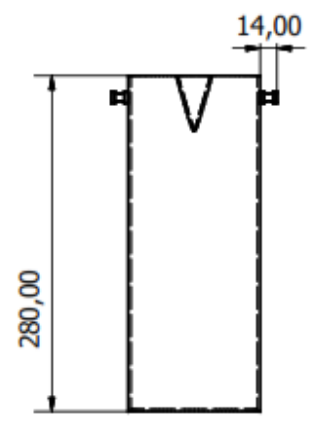

Tampak Depan
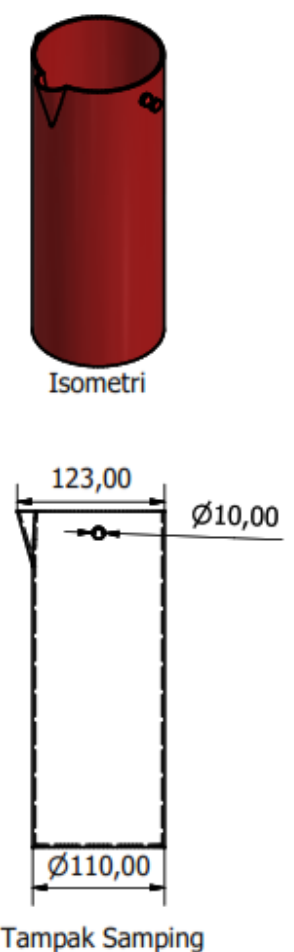

Gambar 5. Desain cawan b. Pembuatan mekanisme tutup tungku

Sisa potongan tabung gas bekas dibuat lubang saluran menguapan diameter $25,4 \mathrm{~mm}$, pada bagian tepi tengah dipasang dilas handel pemutar dari bahan baja pejal diameter $16 \mathrm{~mm}$ dengan panjang 420,54 mm. Pada bagian tepi sejajar dengan handel dilas mekanisme engsel dan dihubungkan dengan tuas sejajar tabung dengan panjang tuas 420,54 mm. Mekanisme tutup tungku dapat dilepas dan diputar berlawanan arah jarum jam dengan sudut putar 300 derajat.

c. Pembuatan isolator keramik

Bahan isolator keramik terbuat dari campuran semen tahan api, abu terbang dan tanah liat serta air secukupnya dengan tebal $136 \mathrm{~mm}$. Sebelum campuran adonan ini dituangkan kedalam bodi tungku berdiameter luar $276 \mathrm{~mm}$ dan tinggi 465 $\mathrm{mm}$ terlebih dahulu pada sisi bagian dalam dipasang penyekat ruang bakar dengan diameter 
$140 \mathrm{~mm}$. Setelah penyekat terpasang adonan campuran isolator keramik dituangkan kedalam bodi sampai terisi penuh dan didiamkan sampai kering. Setelah isolator keramik padat maka penyekat dikeluarkan dan pada bagian sisi ruang bakar dipasang penyangga cawan dari baja pejal diameter $14 \mathrm{~mm}$ berbentuk lingkaran dimana pada ke empat sisinya ditanam pada dinding isolator keramik dengan jarak 156,2 mm dari alas.

d. Pembuatan Cawan

Cawan dibuat dari pipa berdiameter $110 \mathrm{~mm}$ dan panjang $280 \mathrm{~mm}$. Pada bagian tepi atas dibentuk moncong berbentuk segitiga lancip sebagai tempat mengeluarkan logam cor. Untuk mengangkat cawan kedua sisi kiri dan kanan bagian atas kowi dilaskan baja pejal diameter 10 $\mathrm{mm}$ yang diberi alur pada bagian tengahnya.

Setelah didesain dan dibuat, tungku krusibel kemudian dipasangkan komponen pendukung diantaranya pemasangan gas sebagai sumber panas dan pemasangan blower sebagai sumber tekanan udara.

\section{Uji Coba Kinerja Tungku Krusibel}

1. Suhu maksimum yang dapat dicapai tungku krusibel

Pada pengujian ini, tungku dinyalakan dengan pembukaan penuh katup gas dan udara blower kemudian suhu diukur pada ruang bakar dengan menggunakan digital thermometer thermocouple sensor tipe $\mathrm{K}$ dan hasilnya dicatat secara manual data yang ada di layar display alat ukur pada setiap 60 detik.

Pada gambar 7 menunjukkan kenaikan suhu dalam setiap detik, dimana semakin lama dipanaskan maka semakin tinggi suhu yang dihasilkan oleh tungku krusibel berbahan bakar gas LPG. Suhu maksimum yang dicapai $1367^{\circ} \mathrm{C}$ selama 900 detik (15 menit) dengan komsumsi bahan bakar gas LPG sebesar 0,5 $\mathrm{kg}$ dengan jumlah bahan aluminium $0,5 \mathrm{~kg}$. Untuk pengukuran temperatur luar (dinding) sebesar $67{ }^{\circ} \mathrm{C}$. Perbedaan suhu dalam ruang bakar dan suhu dinding memiliki perbandingan yang sangat jauh karena direduksi oleh bahan isolator dari bahan keramik yang ada pada tungku. Hasil penelitian (Adi, Raharjo, \& Surojo, 2014) bahwa panas tungku tahanan listrik dapat menghasilkan suhu hingga $800{ }^{\circ} \mathrm{C}$ selama 58 menit. Logam aluminium melebur pada suhu $660^{\circ} \mathrm{C}$ (Wiyono, Riatna, \& Nurkholis, 2018), (Adi,
Raharjo, \& Surojo, 2014) (Callister, 2007). Sehingga dengan menggunakan tungku krusibel ini dicapai dengan waktu \pm 753 detik (12,55 menit).



Gambar 6. Pencatatan temperatur pada tungku



Gambar 7. Distribusi suhu terhadap waktu

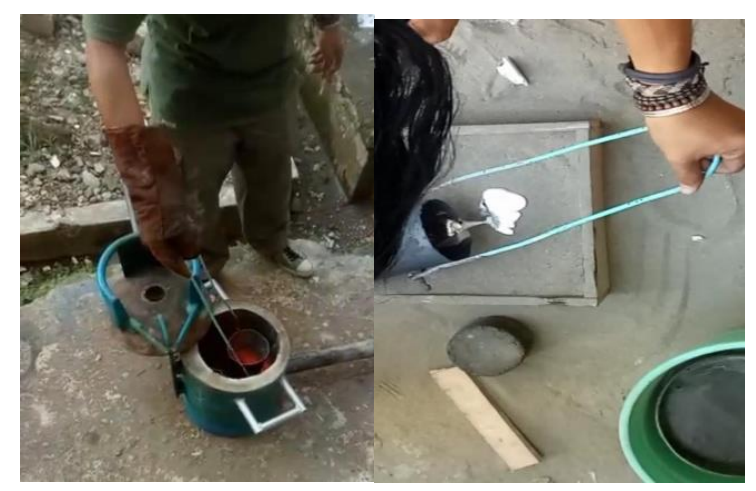

Gambar 8. Hasil perancangan tungku krusibel dan ji coba pengecoran logam

2. Peleburan aluminium

Peleburan aluminium dilakukan sebanyak tiga kali percobaan seperti yang ditampilkan pada tabel di bawah ini.

Tabel 1. Berat aluminium yang dilebur terhadap lama waktu yang dibutuhkan setiap percobaan

\begin{tabular}{cc}
\hline Berat $\mathrm{Al}(\mathrm{kg})$ & Waktu peleburan $(\mathrm{s})$ \\
\hline 0,5 & 660 \\
1,0 & 960 \\
1,5 & 1200 \\
\hline
\end{tabular}


Pada tabel 1 di atas memperlihatkan bahwa semakin banyak aluminium yang dilebur maka semakin lama waktu yang dibutuhkan untuk mencair. Dari tigal kali percobaan peleburan Aluminium dengan menggunakan bahan bakargas LPG diperoleh berat total $2 \mathrm{~kg}$ selama 2820 detik (47 menit). Jika dibandingkan dengan tungku peleburan berbahan bakar gas LPG yang dirancang dan dibuat oleh (Mubarak \& Akhyar,, 2013) hanya dapat meleburkan $0,39 \mathrm{~kg}$ aluminium dalam waktu 30,15 menit. Sedangkan penelitian perancangan dan pembuatan tungku peleburan dengan menggunakan oli bekas yang dilakukan (Akhyar, 2014) mampu meleburkan $1 \mathrm{~kg}$ Aluminium dalam waktu 50 menit 32 detik.

3. Konsumsi bahan bakar gas

Konsumsi bahan bakar gas LPG diukur berdasarkan waktu yang dibutuhkan terhadap berat gas LPG yang dikonsumsi dan aluminium yang dilebur. Untuk pengaturan suplay gas LPG digunakan brander (torch) yang dihubungkan dengan saluran masuk. Berdasarkan pengujian diperoleh bahwa $3 \mathrm{~kg}$ gas LPG habis selama 3600 detik (60 menit) dengan berat alumunium yang dilebur sebesar $5 \mathrm{~kg}$.

\section{PENUTUP}

\section{Kesimpulan}

Kesimpulan dari hasil desain dan pengujian data yang telah dilakukan, maka dapat disimpulkan bahwa tabung gas bekas berhasil didesain dan dimanfaatkan sebagai tungku krusibel yang mampu meleburkan Aluminium sebanyak $5 \mathrm{~kg}$ dalam waktu 60 menit dengan komsumsi bahan bakar $3 \mathrm{~kg}$. Panas pada ruang bakar dapat mencapai temperatur 1367 ${ }^{\circ} \mathrm{C}$ dan temperatur dinding luar berkisar $67{ }^{\circ} \mathrm{C}$ dengan volume ruang bakar $1424,78 \mathrm{~mm}^{3}$.

\section{Saran}

Saran untuk penyempurnaan tungku krusibel dapat menambahkan mekanisme pengatur kecepatan udara blower dan perlu dikembangkan lebih lanjut bahan isolator keramik untuk memperbaiki efisiensi panasnya.

\section{DAFTAR PUSTAKA}

Adi, I. M., Raharjo, W. P., \& Surojo, E. (2014, Sepetember). Rancang Bangun Tungku Pencairan Logam Aluminium Berkapasitas 2 KG Dengan Mekanisme Tahanan Listrik. Mekanika, 13(1), 21-32.

Akhyar. (2014). Perancangan dan Pembuatan Tungku Peleburan Logam Dengan Memanfaatkan Oli BekasSebagai Bahan
Bakar. Seminar Nasional Sains dan Teknologi (pp. 1-6). Jakarta: Fakultas Teknik Universitas Muhammadiyah .

Ana, G., Wanga, Y., Lia, W., \& Liub, J. (2012). Research on Key Designing Parameters of Destruction Furnace for Explosive Waste. Procedia Enviromental Science 16-Science Direct, (pp. 202-207). New York.

Arianto, S. L., Tiwan, T., \& Mujiyono, M. (2017). Tungku Krusibel Dengan Economizer Untuk Praktik Pengecoran Di Jurusan Pendidikan Teknik Mesin FT UNY. Jurnal Dinamika Vokasional Teknik Mesin, 21-27.

Arifin, S. (1976). Ilmu Logam (Jilid 1 ed.). Jakarta: Ghalia Indonesia.

Callister, W. D. (2007). Materials Science and Engineering. United States of America: Jhon Wiley \& Sons.

Hill, R. C., (1979). Design Construction and Performance of Stick-Wood Fire Furnace for Residental and Commercial Aplication. University of Maine Orono, (pp. 1-7). Maine.

Irvan, A., \& Suryadi. (2017, Januari). Sistem Peleburan Logam Berbahan Gas Untuk Industri Kecil dan Menengah. ELEKTRA, 2(1), 50-57.

Jami, A., \& Prayitno. (2015, November 2015 ). Desain Electric Furnace Untuk Proses Dekomposisi Thermal Thorium Oxalate Hexahydrate. Prima, 12(2). Retrieved Februari 2020

Leman, A., Ristadi, F. A., Gilang, A., Bima, B., \& Dwi, G., (2019, April). Prototipe Tungku Krusibel Mini. Dinamika Vokasional Teknik Mesin, 4(1), 45-53.

Mubarak, A. Z., \& A. A. (2013, Juni). Perancangan dan Pembuatan Dapur Peleburan Logam Dengan Menggunakan Bahan Bakar Gas. Jurnal Teknik Mesin Unsyiah, 1(3), 128-132.

Stana, B. I., Ridwan, A., \& Rilnanda, A. (2017, Oktober). Optimasi Tungku Peleburan logam Aluminium Kapasitas $10 \mathrm{~kg}$. Jurnal Photon, 8(1), 167-173.

Wiyono, A., Riatna, D., \& Nurkholis, I. (2018). Studi Eksperimen Efisiensi Tungku Peleburan Aluminium Dengan Briket Tempurung Kelapa Melalui Force Convection. Subang, Indonesia: Konferensi Ilmiah Teknologi Texmaco. 